\title{
Keanekaragaman Jenis Lumut (Musci) di Lereng Gunung Wani, Suaka Margasatwa Buton Utara, Sulawesi Tenggara
}

\author{
Mosses Diversity in Slope of Wani Mountain, North Buton Wild Life Reserve, South-East \\ Sulawesi
}

\section{Florentina Indah Windadri}

Bidang Botani, Pusat Penelitian Biologi, Cibinong Science Centre-LIPI Cibinong, Jawa Barat E-mail:herbogor@indo.net.id

\begin{abstract}
Diversity study on mosses at the slope of Wani mountain, North Buton Wild Life Reserve, South-east Sulawesi was conducted. There are 26 species belong to 14 genera and 8 families are recorded. Two genera i.e. Thuidium and Himanthocladium dominated in this area. Sixth species are recorded as "new record" to Sulawesi i.e. Barbella pendula, Calyptothecium caudatum, Himantocladium plumula, Pinatella ambigua, Taxithelium alare, and Thuidium investe.
\end{abstract}

Key words: diversity, mosses, North Buton Wild Life Reserve, South-east Sulawesi

Diterima: 23 Agustus 2007, disetujui: 06 Desember 2007

\section{Pendahuluan}

Lumut merupakan kelompok tumbuhan kecil yang tumbuh menempel pada substrat berupa pohon, kayu mati, kayu lapuk, serasah, tanah, dan batuan. Di dalam kehidupannya, faktor lingkungan sangat berpengaruh, seperti dilaporkan Richard (1984) bahwa iklim mikro lebih berpengaruh pada pertumbuhan dan perkembangan lumut dari pada faktor makro. Selain itu, dilaporkan satu pohon merupakan habitat komplek bagi lumut. Perlekatan dan ketahanan hidupnya pada pohon akan dipengaruhi oleh karakter perubahan kulit kayu dari ranting yang termuda hingga cabang yang tua. Demikian juga dengan intensitas cahaya yang sampai pada permukaan pohon tersebut (Richardson, 1981).

Sulawesi dikenal sebagai salah satu pulau dengan keanekaragaman hayati cukup tinggi dan keunikan floranya. Penggalian keanekaragaman hayati Sulawesi hingga kini masih belum menyeluruh termasuk diantaranya kelompok tumbuhan rendah (lumut) yang merupakan salah satu komponen keanekaragaman hayati. Beberapa orang peneliti pernah melakukan koleksi lumut di beberapa daerah di Sulawesi diantaranya A.H. Everett (1892, 1893, 1898), Bunnemeijer (1921), H.R.H. Prince Leopold (1921, 1929), Kjellberg (1929) yang telah mengumpulkan 106 jenis (Dixon,1939). Peneliti lainnya seperti Windadri (1996) juga pernah mengoleksi sebanyak 23 jenis dari kawasan Taman Nasional Bogani Nani WartaBone, Sulawesi Utara. Di sekitar pulau Sulawesi terdapat deretan pulau-pulau kecil dan salah satu di antaranya Buton yang termasuk dalam provinsi Sulawesi Tenggara. Di pulau ini terdapat tiga kawasan konservasi yaitu Suaka Margasatwa Buton Utara yang terletak di Kabupaten Muna, Suaka Margasatwa Lambusango dan Cagar Alam Kakenauwe di Kabupaten Buton.

Suaka Margasatwa Buton Utara secara geografis berada pada posisi $4^{0} 26^{\prime}-4^{0} 54^{\prime}$ LS dan $122^{\circ} 48^{\prime}$ - $123^{\circ} 11^{\prime}$ BT. Luas kawasan konservasi ini mencapai 82.000 ha dengan topografi bergelombang sampai berbukit. Di dalam kawasan ini terdapat Gunung Wani yang tingginya mencapai $1190 \mathrm{~m}$ di atas permukaan laut. Jenis tanahnya mediteranian dan podzolik merah kuning, di beberapa tempat sering 
dijumpai batu karang atau koral dengan lapisan tanah pucuk tipis. Keanekaragaman jenis tumbuhannya cukup tinggi dengan didukung oleh berbagai tipe ekosistem yang ada, yaitu hutan bakau, hutan pantai, hutan pamah dan hutan pegunungan bawah (Anonim, 1999).

Penelitian tentang keanekaragaman floranya pernah dilakukan, namun penelitian secara khusus pada keanekaragaman tumbuhan rendah (Bryophyta) belum banyak dilakukan. Hal ini ditunjukkan antara lain dari hasil pengecekan spesimen koleksi di Herbarium Bogoriense yang hanya menemukan satu jenis koleksi Kjellberg yaitu Acroporium decipiens (Dix.) Broth berasal dari daerah Kaboengka, Pulau Buton (Dixon, 1939) dan koleksi Uji et al., (2003) sebanyak 4 jenis dari kawasan Suaka Margasatwa Buton Utara, wilayah kecamatan Maligano. Oleh karena itu, perlu kiranya dilakukan pengungkapan kekayaan flora lumut dengan harapan akan dapat menambah dan melengkapi keanekaragamanan flora di kawasan ini.

\section{Metode Penelitian}

Penelitian dilakukan dengan metoda jelajah yaitu menjelajahi setiap sudut lokasi penelitian (Rugayah et al., 2004). Semua jenis lumut yang dijumpai dikumpulkan, diberi nomor dan dicatat data lapangannya, meliputi. habitat, substrat, warna, ketinggian tempat, dan kegunaannya (jika ada). Spesimen lumut yang dikoleksi kemudian dikering anginkan, selanjutnya dibuat herbarium untuk keperluan identifikasi. Beberapa buku acuan yang digunakan dalam identifikasi antara lain ' $A$ Handbook of Malesian Mosses, volume 1 dan 2' (Eddy, 1988 dan 1990), 'Mosses of The Philippines' (Bartram, 1939), 'Mosses and Liverworts of Hong Kong, volume 1'(So, 1995), dan spesimen koleksi yang tersimpan di Herbarium Bogoriense. Lumut yang telah teridentifikasi diproses sebagai koleksi dan disimpan di Herbarium Bogoriense.

\section{Tempat dan waktu penelitian}

Lokasi penelitian di lereng gunung Wani, Suaka Margasatwa Buton Utara, pada ketinggian 200-600 m di atas permukaan laut dengan kemiringan lereng mencapai $60^{\circ}$.
Lokasi ini berupa hutan primer dengan satu sungai di dalamnya yaitu sungai Tobelo. Tepi sungainya ditemukan tumpukan serasah dan kayu-kayu mati. Waktu penelitian dari bulan April sampai dengan Mei 2004, bertepatan dengan musim penghujan di kawasan ini.

\section{Hasil dan Pembahasan}

Dari hasil koleksi lumut di lokasi penelitian tercatat 44 nomor yang terdiri atas 26 jenis, 14 marga dan 8 suku (Tabel 1).

Berdasarkan Tabel 1, tampak bahwa lumut ditemukan di tepi sungai pada substrat berupa batang dan ranting pohon, kayu lapuk, batuan atau tanah. Pertumbuhan dan perkembangan lumutnya cukup bagus, dan populasinya relatif melimpah, karena kondisi alamnya seperti sungai dan anak sungai yang tidak pernah kering membuat lingkungan lembab. Rapatnya pepohonan di tempat ini menyebabkan intensitas cahaya yang masuk tidak terlalu tinggi sehingga membuat lingkungan menjadi teduh. Keadaan seperti ini sangat mendukung pertumbuhan dan perkembangan lumut, seperti dilaporan Richard (1984) dan Richardson (1981).

Pengamatan di kawasan lereng Gunung Wani menunjukkan bahwa lumut umumnya tumbuh di batang- batang pohon atau akar-akar pohon yang muncul kepermukaan tanah. Meskipun kelembaban lingkungan cukup tinggi tetapi karena kemiringan lereng cukup tajam mengakibatkan substrat-substrat pertumbuhan lumut seperti serasah, kayu mati, kayu lapuk, dan tanah mudah hanyut terbawa air hujan dan menumpuk di tepi-tepi sungai. Dengan demikian lantai hutan umumnya berupa bebatuan serta akar-akar pohon yang muncul kepermukaan tanah. Di lokasi ini, batu-batu sebagai salah satu substrat lumut, banyak ditumbuhi ganggang. Substrat yang tersisa di lantai hutan untuk pertumbuhan lumut hanya akar-akar pohon yang muncul kepermukaan tanah. Akar-akar dengan lapisan tanah sangat tipis mampu menahan spora-spora lumut yang jatuh, selanjutnya berkecambah dan tumbuh menjadi tumbuhan lumut baru.

Sebanyak 12 marga (terdiri atas 19 jenis) lumut ditemukan di tepi sungai, dua di antaranya 
kedapatan melimpah yaitu Himantocladium yang tumbuh di kayu-kayu lapuk dan Thuidium di bebatuan. Bartram (1939) melaporkan bahwa kedua marga ini umumnya tumbuh bersubstrat bebatuan lembab, akar, batang atau ranting pohon. Pada pengamatan di lereng G. Wani, kedua marga ini tidak ditemukan. Hal ini dimungkinkan karena substratnya yang berupa bebatuan atau akar pohon telah didominasi oleh pertumbuhan algae (ganggang).
Disamping itu pepohonannya tumbuh lurus dan ranting-rantingnya berada di ujungujung batang. Pada kondisi lingkungan seperti ini jarang ditemukan pertumbuhan lumut karena kelembabannya relatif lebih rendah dibandingkan di bagian bawah (mendekati lantai hutan).

Untuk mengenal keragaman lumut di lokasi penelitian dapat diketahui melalui kunci identifikasi suku.

Tabel 1. Daftar Jenis Lumut di Kawasan Suaka Margasatwa Buton Utara, Wilayah Kecamatan Wakarumba, Kabupaten Muna, Sulawesi Tenggara

\begin{tabular}{clcc}
\hline \hline No. & \multicolumn{1}{c}{ Nama Suku / Jenis } & Substrat & Lokasi \\
\hline \hline & CALYMPERACEAE & & \\
1 & Calymperes erosum C.Müll. & akar banir & A \\
2 & Calymperes montleyi Mitt. & kulit kayu & A \\
3 & Calymperes serratum Braun \& C. Müll. & batu coral & B \\
4 & Calymperes tenerum C. Müll. & kulit kayu & A \\
5 & Mitthyridium undulatum (Doz. et. Molk.) Robinson & kayu mati & B \\
6 & Mitthyridium jungquilianum (Mitt.) Robinson & kulit kayu & A \\
7 & Syrrhopodon aristifolius Mitt. & kayu mati & B \\
8 & Syrrhopodon trachyphyllus Mont & batuan & B \\
& FISSIDENTACEAE & & \\
9 & Fissidens areolatus Griff. & batuan & B \\
10 & Fissidens robinsonii Broth. & batu & B \\
11 & Fissidens sylvaticus Griff. & tanah & B \\
& HYPNACEAE & & \\
12 & Ectropothecium ichnotocladum (C.Müll.) Jaeg. & kayu lapuk & B \\
13 & Ectropothecium dealbatum (Hornsch. \& Reinw.) Jaeg. & kulit kayu & A \\
14 & Isopterygium bancanum (Lac.) Jaeg. & batuan & B \\
15 & Isopterygium albescens (Schwaegr.) Jaeg. & batuan & B \\
& METEORIACEAE & & \\
16 & Barbella pendula (Sull.) Fleisch. & ranting pohon & B \\
& NECKERACEAE & & \\
17 & Himantocladium cyclophyllum (C.Müll.) Fleisch. & kayu lapuk & B \\
18 & Himantocladium loriforme (Lac.) Fleisch. & kayu lapuk & B \\
19 & Himantocladium plumula (Nees) Fleisch. & kayu lapuk & B \\
20 & Neckeropsis lepineana Mont. & ranting pohon & B \\
21 & Pinnetella ambigua (Lac.) Fleisch. & perakaran rau & A \\
22 & Calyptothecium caudatum Bartram & kayu mati & B \\
23 & BarTIACEAE & & \\
24 & Taxithelium alare Broth. & batuan & B \\
& THUIDIACEAE & & \\
25 & Thuidium investe (Mitt.) Jaeg. & batuan kayu & A \\
26 & batuan & B \\
\hline \hline & & & B \\
\hline
\end{tabular}

Keterangan: A = lereng G. Wani $\quad B=$ tepi sungai Tubelo 
Kunci identifikasi suku:

1 a. Tumbuhan umumnya akrokarpus (tumbuh tegak).................................. 2

b. Tumbuhan umumnya pleurokarpus (tumbuh merayap/ menggantung)............... 4

2 a. Daun tersusun dalam dua deret dan mempunyai duplikat daun berbentuk seperti perahu (lamina vaginant)

b. Daun tersusun lebih dari dua deret, tanpa duplikat daun.

3 a. Daun berligula

3

b. Daun tidak berligula

4 a. Batang bercabang menyirip sederhana,

b. Batang menyirip rangkap, merayap pada substratnya

5 a. Daun pipih dan bergelombang

b. Daun tidak bergelombang.

6 a. Cabang membelit,

b. Cabang menggantung....

7 a. Sel-sel alar kecil, tidak dapat dibedakan dengan sel-sel disekitarnya.

b. Sel-sel alar berukuran besar, berwarna coklat.

Fissidentaceae

Pottiaceae

Calymperaceae

5

Thuidiaceae

Neckeraceae

6

Meteoriaceae

7

Hypnaceae

Sematophyllaceae

\section{Calymperaceae}

Umumnya tumbuh mengelompok dan
tegak (akrokarpus) jarang menjalar
(Pleurokarpus) kecuali marga Mitthyridium.
Pada ujung daun kadang-kadang terdapat reseptakel menyerupai kuncup (gemma). Sporofit terminal. Tiga marga dari suku ini ditemukan di lokasi penelitian.

Kunci identifikasi marga:

1 a. Lumut tumbuh tegak,

2 a. Tepi daun terdapat sel-sel pembatas.

b. Tepi daun tidak dengan sel-sel pembatas

Calymperes Sw., dalam Web., Tab. Exh. Calyptr. Operc. Gen. (1813); dalam Broth. dalam Naturl. Pflanzenfam. 10: 236 (1924)

Tumbuhan berbatang sederhana atau bercabang, membentuk bantalan. Daun dua macam bentuk (berkuncup dan tidak berkuncup), ramping hingga melebar berbentuk tong. Kuncup (gemma) merupakan modifikasi dari ujung daun, berkelompok, kadang-kadang berbentuk benang dan bercabang. Lamina dibedakan menjadi dua yaitu lamina jernih dan
2

Mitthyridium Syrrhopodon Calymperes

Kunci identifikasi jenis

1 a. Pangkal batang berrizoid............................................................................... . serratum

b. Pangkal batang tidak berrizoid............................................................. 2

2 a. Tumbuhan berukuran kecil (kurang dari $1 \mathrm{~cm}$ tingginya) ................................................ C. tenerum

b. Tumbuhan lebih dari $1 \mathrm{~cm}$ tingginya...................................................... 3

3 a. Daun berkerut jika kering, kosta berakhir pada atau sesudah ujung daun....................... C. erosum

b. Daun terlipat jika kering, kosta berakhir sebelum ujung daun ....................................... C. Montleyi

Calymperes erosum C. Mull, dalam Linnaea 21: 182 (1848)

Sinonim: Calymperes hampei Dozy \& Molk., dalam Bryol. Javanica 1:48(1856); Calymperes naumanii Besch, dalam Annls Sci. nat. Bot., Ser. 8 (1):267 (1896); Calymperes stenogaster Besch., dalam Annls Sci. nat. Bot., Ser. 8(1): 267 (1896).

Hijau kekuningan, tinggi mencapai $5 \mathrm{~cm}$, mengelompok. Daun mengkilat, melengkung; 
pangkal melebar; kosta tebal, berakhir di ujung daun pada daun normal, di luar ujung daun pada daun berkuncup, berujung runcing atau meruncing dan bergigi. Sel-sel lamina pada sisi adaxial bermamila, sedang sisi abaxial berpapila. Sporofit jarang ditemukan, jika ada seta kemerahan, panjang 3-5 mm.

Ekologi dan persebaran: Umumnya tumbuh di ranting, cabang dan perakaran pohon di tempat terbuka pada ketinggian kurang dari $500 \mathrm{~m}$ di atas permukaan laut, kadang-kadang ditemukan di tanah lembab dengan kondisi lingkungan teduh (Ellis dan Tan, 1999). Di lokasi penelitian tumbuh di bebatuan, tanah lembab, dengan kondisi lingkungan sekitarnya terang atau terbuka. Persebarannya meliputi: daerah-daerah tropis, di kawasan Malesia ditemukan melimpah (Eddy, 1990). Pengecekan spesimen: A. Touw dan M. Snoek 24687, Rantepao, Tana Taroja; FIW/ SMBU/ 44, G. Wani, Sultra.

Calymperes montleyi Mitt., Dozy \& Molk., dalam Bryol. Javanica 1:48(1856)

Sinonim: Calymperes chamissonis Besch., Annls Sci. nat. Bot., Ser. 8 (1):280 (1896).

Hijau kekuningan, tinggi mencapai $1,5 \mathrm{~cm}$, membentuk bantalan. Daun tidak berkuncup membundar telur. Daun berkuncup menyerupai tong, costa lebih tebal, kuncup di sisi ventral. Sel-sel lamina membundar atau persegi, kolenkimatus (terdapat penebalan dinding sel di bagian sudut-sudutnya), sisi adaxial sangat cembung, sisi abaxial rata, bagian tengahnya berpapila.

Ekologi dan persebaran: tumbuh di batang pohon di hutan-hutan terbuka pada ketinggian rendah. Jenis ini di kawasan Malaysia tidak begitu melimpah. Selain itu juga ditemukan di Polynesia dan Australia bagian utara (Eddy, 1990). Dilokasi penelitian jenis ini (FIW/SMBU/46, G. Wani, Sultra) tumbuh bersubstrat batang pohon di lingkungan terbuka.

Calymperes serratum Braun ex C. Mull., dalam Syn. Musc. Frond. 1:527 (1849)

Sinonim: Calymperes subserratum Fleisch., dalam Musci Fl. Buitenzorg 1:245 (1904); Calymperes clemensiae Broth., dalam Philipp. J. Sci. C. Bot. 8:69 (1913).

Hijau, tinggi lebih dari $2 \mathrm{~cm}$, membentuk batalan, batang sangat pendek atau tidak ada, mempunyai percabangan bebas, rhizoid coklat kemerahan. Daun memita, pangkal pendek melebar, tepi bergigi tidak teratur, kosta menonjol di bagian bawah. Kuncup (gemma) dihasilkan di bagian ventral maupun dorsal dari kosta mendekati ujung daun, kuncup kadangkadang bercabang. Sel-sel lamina kecil, berdinding tebal dengan lumen membundar telur. Sporofit jika ada, panjang setanya 4-6 mm.

Ekologi dan persebaran: umumnya tumbuh di ranting-ranting pohon pada ketinggian mencapai $1000 \mathrm{~m}$ di atas permukaan laut (Ellis dan Tan, 1999). Di lokasi penelitian tumbuh di batang pohon dalam hutan, di lingkungan terang. Jenis ini dilaporkan tersebar di Afrika tropis, Sri Lanka dan Thailand hingga Malesia, Polynesia dan Australia bagian utara (Eddy, 1990). Pengecekan spesimen: Uji (4794, 4788, 4793), Suaka Margasatwa Buton Utara, Sultra; FIW/SMBU/7 \& FIW/SMBU/20, S. Tubelo, Sultra.

\section{Calymperes tenerum C. Mull., dalam Linnaea 37: 174 (1872)}

Sinonim: Calymperes pachyneurum C.Mull., dalam Journ. Mus. Godeffroy 3(6):65 (1874); Calymperes pandani C. Mull., dalam Bot. Jb. 5:87 (1875); Calymperes kaernbachii Broth., dalam Bot. Jb. 17: 477 (1893); Calymperes bataviense Fleisch., dalam Musci Fl. Buitenzorg 1:276 (1904); Calymperes aruense Bartr., dalam Farlowia 1:43 (1943).

Daun membundar telur, ujung melebar runcing, kosta berakhir di luar ujung daun, tepi rata menggulung jika kering, Kuncup di permukaan ujung daun. Sel-sel lamina berdinding tipis, sel-sel kosong terjadi $1 / 2$ lebar pangkal daun dan terdiri dari 4-7 deret sel-sel besar.

Ekologi dan persebaran: tumbuh di batang pohon, kayu mati, permukaan akar yang terbuka, batuan (Ellis \& Tan, 1999). Di lokasi penelitian tumbuh di batang pohon. Jenis ini banyak ditemukan di daerah dekat pantai di kawasan Asia tropis (Eddy, 1990). Pengecekan spesimen: FIW 826, TN. Bogani Nani Wartabone, Sulut; FIW/SMBU/ 21, Gn. Wani, Sultra. 
Mitthyridium (Mitt.) Robinson, dalam Phytologia 32: 432 (1975)

Sinonim: Thyridium Mitt., dalam Journ. Linn. Soc. Bot. 10: 188 (1868).

Batang utama menjalar, bercabang tegak, memberkas, hijau atau kekuningan; rhizoid melimpah. Daun-daun cabang menyebar, lamina bergelombang, berkerut dan keriting jika kering; pangkalnya terdapat sel-sel jernih, tepinya berpembatas lebar, ujung meruncing. Kosta berkembang baik, berakhir sebelum ujung daun, halus di bagian pangkal, dan kasar di bagian atas, pita stereid berkembang baik. Sel-sel lamina bagian atas kecil, transparant, berpapila banyak. Sel-sel kosong berukuran besar dan mendominasi pangkal daun, sel-sel leukosis persegi, berlubang besar di luarnya. Seta ramping, halus; kapsul silindris. Dua jenis dari anggota marga ini ditemukan di lokasi penelitian.

Kunci identifikasi jenis:

1. a. Tumbuhan kecil, panjang cabang kurang dari $2 \mathrm{~cm}$. Sel-sel pembatas berakhir sebelum ujung daun; sel-sel kosong menempati 1/5-1/7 pangkal daun. M. jungquilianum

b. Tumbuhan medium, panjang cabang mencapai $4 \mathrm{~cm}$. Sel-sel pembatas melengkung kuat di bagian atas, sel-sel kosong menempati 1/3-1/4 pangkal daun M. Undulatum

\section{Mitthyridium jungquilianum (Mitt.) Robinson, dalam Phytologia 32: 433 (1975)}

Sinonim: Syrrhopodon jungquilianus Mitt., Dozy \& Molk., dalam Bryologia javanica 1:57(1856); Syrrhopodon subluteus C.Mull., dalam Journ. Mus. Godeffroy 3(6): 67 (1874); Syrrhopodon perundulatus Broth., dalam Schum. \& Lauterb., Fl. Deutsch. Schutzgeb. Sudsee: 83 (1900); Mitthyridium subluteum (C.Mull.) Nowaj., dalam Bryophytorum Bibliotheca 20:144 (1980).

Hijau pucat atau kekuningan, lembut. Daun linear-lanset, menyebar agak tegak jika basah, terpuntir jika kering; tepi bergelombang. Sel-sel lamina bagian atas berdinding tebal.

Ekologi dan persebaran: Umumnya tumbuh di ranting atau cabang pohon, di kawasan Malesia dan Pasifik bagian barat (Eddy, 1990). Di lokasi penelitian jenis ini (FIW/SMBU/ 11, G. Wani, Sultra) tumbuh di kayu-kayu mati tepi sungai.

\section{Mitthyridium undulatum (Dozy \& Molk.) Robinson, dalam Phytologia 32: 435 (1975)}

Sinonim: Codonoblepharum undulatum Dozy \& Molk., dalam Musc.Frond.Archip.Ind. 96 (1849),pl.32v.; Syrrhopodon adpressus Broth., dalam Ofvers.finska Vatensk Soc. Forh. 40: 166 (1898); Thyridium geheebii (Par.) Fleisch., dalam Bot. Jb. 55:29 (1917); Thyridium binsteadii (Ther. \& Dix.) Broth., dalam Naturl. Pflanzenfam., $2^{\text {nd }}$ ed., 10: 236 (1924); Thyridium pungens (Dix.)Broth., dalam Naturl. Pflanzenfam., $2^{\text {nd }}$ ed., 11: 527 (1925);
Mitthyridium adpressum (Broth.) Robinson, dalam Phytologia 32 : 432 (1975).

Tubuh lebih kecil dari $M$. fasciculatum dan lebih besar dari M. jungquilianum. Daun tersebar tegak jika basah, kadang-kadang kaku, bergelombang. Kosta halus, jernih dan berakhir mendekati ujung. Sel-sel lamina bagian atas persegi tidak beraturan. Gemma (kuncup) jika ada terbentuk di sisi adaxial kosta di bawah ujung daun.

Ekologi dan persebaran: umumnya ditemukan di dekat pantai. Di lokasi penelitian tumbuh di batang pohon di hutan lereng gunung. Daerah persebarannya meliputi Asia tropis, Malesia dan Polynesia (Eddy, 1990). Pengecekan spesimen: A. Touw \& M. Snoek 24344 \& 24448b; Rantepao, Tana Toraja; FIW/SMBU/35, S. Tubelo, Sultra.

\section{Syrrhopodon Schwaegr., dalam Sp. Musc. Frond. Suppl. 2: 110 (1824)}

Merupakan marga yang heterogen, memberkas, tinggi mencapai $10 \mathrm{~cm}$, tetapi umumnya kurang dari $4 \mathrm{~cm}$. Berkasnya jarang atau rapat dengan rhizoid di bagian yang lebih tua. Batang tipis, gelap. Daun bervariasi, ramping, tegak, pangkalnya melekat dan mengelilingi batang, ujung bervariasi, tepi berpembatas. Kosta halus atau berpapila, biasanya dengan satu lapisan penutup dari selsel pendek, berakhir pada atau mendekati ujung daun. Pangkal daun didominasi oleh sel-sel kosong, persegi, jernih, berdinding tipis. 
Sel-sel lamina berkhlorofil, sel-sel pembatas terdiri atas sel-sel memanjang. Kapsul muncul dari seta yang tipis dengan bermacam-macam ukuran (biasanya 4-15 mm), silindris, tutup kapsul tegak, berseludangberparuh; peristom sederhana, terdiri atas 16 gigi, ramping, berpapila kasar; kaliptra relatif ramping, gugur jika tua. Dua jenis dari marga ini ditemukan di lokasi penelitian dan mudah dibedakan dari bentuk perawakannya. Pada Syrrhopodon aristifolius mempunyai ukuran lebih besar dan memberkas seperti rumput, daun lebih panjang dari batangnya, sedangkan pada Syrrhopodon trachyphyllus berkas memipih, tepi daun menggulung ke dalam jika kering.

Syrrhopodon aristifolius Mitt., dalam J. Linn. Soc. Bot. 10: 176 (1868)

Sinonim: Syrrhopodon subulatus Lac., dalam Verh.K. Akad. Wet., Amst., Afd. Natuurk. 13(2): 5 (1872); Syrrhopodon fallax Lac., dalam Verh. K. Akad. Wet., Amst., Afd. Natuurk. 13(2): 5 (1872).

Hijau tua atau coklat, tidak berbatang atau jika ada tingginya mencapai $10 \mathrm{~mm}$. Daun memberkas, memita dan tersebar tegak, tidak tumpang tindih jika kering, panjang 8-15 mm. Tepi daun terdiri dari satu deret sel di bagian pangkal kemudian menjadi beberapa deret pada helaian daun. Kosta kuat, berakhir pada atau di luar ujung daun dan membentuk kuncup (gemma). Lamina ramping, terdiri 3-7 deret sel di bagian tengah helaian; sel-sel membundarpersegi, cembung pada sisi adaxial, rata pada sisi abaxial, halus. Sel-sel kosong relatif kecil, menempati $1 \frac{1}{2}$ dari helaian daun. Sporofit jarang ditemukan, jika ada panjang setanya 8-15 mm, kapsul setipe dengan marga.

Ekologi dan persebaran: umumnya tumbuh di kayu mati, batang pohon, pada ketinggian kurang dari $150 \mathrm{~m}$ di atas permukaan laut, jarang di ketinggian lebih dari $500 \mathrm{~m}$ di atas permukaan laut (Eddy, 1990). Di lokasi penelitian ditemukan tumbuh di kayukayu mati tepi sungai. Pengecekan spesimen: A. Touw \& M. Snoek 24368, Rantepao, Tana Toraja; FIW/SMBU/36, S. Tubelo, Sultra.
Syrrhopodon trachyphyllus Mont., dalam Syll.gen.sp.crypt. : 47 (1856)

Sinonim: Syrrhopodon griffithii Mitt., dalam J.Linn.Soc.Bot., Suppl. 1: 40 (1859); Syrrhopodon cavifolius Lac., dalam Verh. K. Akad. Wet. Amst., Afd. Natuurk.13 (2) : 5 (1872); Syrrhopodon semperi C. Mull., dalam Linnaea 38: 557 (1874); Syrrhopodon richardsii Dix., dalam J. Linn.Soc.Bot 50: 82 (1939); Calymperopsis katemensis Zanten, dalam Nova Guinea Bot. 16: 282 (1964).

Hijau pudar atau kecoklatan, tinggi tidak lebih dari $7 \mathrm{~mm}$. Daun kecil, tersebar tegak dari pangkal yang kecil, lurus atau kadang-kadang melengkung; helaian memita, ujung melebar runcing atau tumpul. Kosta halus jernih dan sedikit kaku pada sisi abaxial helaian daun dan kadang-kadang juga di sisi adaxialnya. Sel-sel lamina bundar-persegi, berdinding tebal, sangat cembung. Sel-sel kosong relatif sedikit. Sporofit jika ada bertipe seperti marga, seta 3-4 mm panjangnya.

Ekologi dan persebaran: tumbuh di batang pohon atau bersifat epilitik di lingkungan teduh dan terbuka, pada ketinggian mencapai $300 \mathrm{~m}$ di atas permukaan laut. Jenis ini banyak ditemukan di pantai Asia tropis dan Malesia, dari Sri Lanka dan Semenanjung Malaya hingga Nugini dan Polynesia, (Eddy, 1990). Di lokasi penelitian ditemukan di bebatuan tepi sungai. Pengecekan spesimen: FIW 817,TN. Bogani Nani Wartabone; FIW/SMBU/ 29, S. Tubelo, Sultra.

\section{Fissidentaceae}

Suku ini hanya mempunyai satu marga yaitu Fissidens. Karakter pokok terletak pada generasi gametofit, terpusat pada daunnya yang tersusun dua sisi (distichous), dan adanya duplikat daun berbentuk seperti perahu ('vaginant lamina') dengan panjang mencapai pertengahan daun di sisi adaksial. Sel-sel lamina bervariasi, berdinding tipis atau menebal, halus, berpapila atau bermamila. Seta mencapai $2 \mathrm{~mm}$ panjangnya, halus atau berpapila; kapsul biasanya kecil, silindris pendek, tegak atau menggantung, tutup berparuh. Peristom jika tidak mereduksi bergigi ganda, berjumlah 16. Marga ini terdiri dari beberapa ratus jenis, tersebar di seluruh 
dunia di beberapa tipe habitat. Meskipun kehadirannya di kawasan Malesia cukup baik, namun di lokasi penelitian hanya ditemukan 3 jenis.

Kunci identifikasi jenis

1 a. Tumbuhan berukuran relatif besar............................................. F. areolatus

b. Tumbuhan berukuran kecil ................................................... 2

2 a. Daun dengan kosta berakhir di luar (setelah) ujung daun ................................... F. robinsonii

b. Daun dengan kosta berakhir sebelum ujung daun .................................. F. Sylvaticus

Fissidens areolatus Griff, dalam Calcutta J. nat.Hist 2: 506 (1842)

Sinonim: Fissidens polypodioides Hedw. var areolatus (Griff.) Wils., dalam Kew J.Bot.2: 294 (1857); Fissidens perpellucidus Dix., dalam J.Linn. Soc. Bot. 50:788 (1935), syn. nov.

Berperawakan seperti palem, panjang (1.0-) 1.5-5.0(-7.0) cm, lebar 5-7 mm, hijau kuning atau coklat jingga. Daun besar, berligula ramping, ujung mengalami pelebaran, membundar atau sedikit terbelah, tepi rata. Kosta kuat di bagian bawah, meramping ke arah ujung dan berakhir di ujung daun. 'Vaginant lamina' menempati $1 \frac{1}{2}$ panjang daun. Lamina dorsal melebar, membulat dan kadangkadang bercuping di pangkalnya, berakhir sebagai patahan pada pangkal kosta. Dinding sel lamina menebal, jernih, halus. Seta 7-11 mm panjangnya: kapsul silindris, besar, $2 \mathrm{~mm}$ panjangnya.

Ekologi dan persebaran: jenis ini tersebar dan mempunyai kisaran jenis ('species range') dari India hingga Jepang dan dari Semenanjung Malaya hingga Nugini (Eddy, 1988). Di lokasi penelitian jenis ini (FIW/SMBU/ 30, S. Tubelo, Sultra) ditemukan di bebatuan tepi sungai dengan lapisan tanah sangat tipis.

Fissidens robinsonii Broth., dalam Philipp. J. Sci. § C, 13:204 (1918)

Tumbuh mengelompok, kecil, tinggi 2-5 $\mathrm{mm}$, hijau hingga kekuningan. Daun tersusun tumpang tindih, 4-12 pasang, pangkal membundar, tepi sangat lemah, bergerigi kecil, kosta lurus, berakhir di luar ujung daun. 'Vaginant lamina' mencapai 1/2 panjang daun, Sel-sel lamina sangat kecil, kadang-kadang lebih besar mendekati kosta. Seta terminal, panjang 2,5 mm, kapsul membulat telur.
Ekologi dan persebaran: umumnya tumbuh di tanah dan batuan, serta dilaporkan hanya di kawasan Indo-Pasifik terutama di Malesia dan Polynesia (Eddy, 1988). Di lokasi penelitian jenis ini (FIW/SMBU/38, S. Tubelo, Sultra) ditemukan di batuan tepi sungai dengan lapisan tanah sangat tipi.

Fissidens sylvaticus Griff. Dalam Not. 429; Ic. Pl. Asiat. 2 (1841)

Sinonim : Fissidens zippelianus Doz. \& Molk., dalam Zoll. Syst. Verz. 29 (1954).

Kekuningan atau coklat cerah. Batang 3$4 \mathrm{~mm}$ panjang, $2.5 \mathrm{~mm}$ lebar termasuk daun. Daun keriting dan terpuntir jika kering, tersebar tegak dengan ujung melengkung jika basah, lanset, mencapai $2 \mathrm{~mm}$ panjang, tepi bergigi kecil dan membundar, kosta jernih, berakhir di ujung. Sel-sel daun tidak beraturan, membundar segi enam atau membundar telur transparan, berpapila kecil. Seta terminal, panjang 2-4 mm, kapsul tegak , membulat telur - silindris.

Ekologi dan persebaran: mudah dikenal sebagai tumbuhan epilithic di tempat-tempat lembab dan teduh (Eddy, 1988). Di Lokasi penelitian tumbuh di tanah, tepi sungai. Daerah persebarannya: Siam, Sumatra, Jawa, Sulawesi, Borneo, dan Hongkong (Bartram, 1939). Pengecekan spesimen: Kjellberg 78, Towoeti Merr; FIW 797, TN. Bogani Nani Wartabone; FIW/SMBU/ 10, S. Tubelo, Sultra.

\section{Hypnaceae}

Tumbuhan berukuran kecil hingga agak besar, biasanya mengkilat, menjalar, padat membentuk jalinan. Batang merayap, bercabang menyirip atau agak menyirip. Daun membundar telur atau membundar telur lanset, meruncing, sering melengkung pada satu arah; kosta pendek dan rangkap atau tidak ada. Selsel lamina biasanya besar, linear, prosenkimatus (ujung dinding sel saling tumpang tindih), halus 
atau berpapila. Seta memanjang, ramping, halus; kapsul membulat telur, tidak simetris, mendatar atau menggantung; peristom biasanya rangkap, tutup kapsul pendek, kaliptra mengangguk. Dua marga dari suku ini yaitu Ectropothecium dan Isopterygium ditemukan di lokasi penelitian. Keduanya dapat dibedakan dari sistem percabangannya. Pada Ectropothecium percabangan menyirip teratur sedangkan pada Isopterygium tidak teratur.

Ectropothecium Mitt., dalam J. Linn. Soc. 12:22 (1869)

Tumbuhan membentuk jalinan ektensif dan tipis. Daun melengkung satu arah, membundar lanset. Bagian bawah mulut kapsul sangat berkerut jika kering, tutupmengerucut. Marga ini umumnya tumbuh di kayu-kayu lapuk lembab di lingkungan teduh. Di lokasi penelitian ditemukan dua jenis yaitu Ectropothecium ichnotocladum yang tergolong tumbuhan berumah dua dan Ectropothecium dealbatum berumah satu.

\section{Ectropothecium ichnotocladum (C.Mull.)} Jaeg., dalam Adumbr. 2 : 523 (1877-1878)

Sinonim: Hypnum ichnotocladum C.Mull., dalam Syn. 2: 301 (1851); Hypnum callichroides C.Mull., dalam Linnaea 38: 562 (1874).

Berperawakan ramping, mengkilat. Batang mencapai $4 \mathrm{~cm}$ panjangnya. Daun berdesakan, ramping-lanset, cekung, tepi bergerigi mulai pertengahan ke arah ujung. Selsel linear, halus, bagian tepi lebih lebar dan persegi ke arah ujung. Seta $1.5 \mathrm{~cm}$ panjangnya, kapsul membulat telur, mendatar atau menggantung.

Ekologi dan persebaran: umumnya tumbuh di batang pohon atau kayu mati. Di lokasi penelitian tumbuh di kayu lapuk, tepi sungai. Daerah persebarannya meliputi Sumatra, Jawa, Borneo, Sulawesi, Ambon, Filipina dan Andaman (Bartram, 1939). Pengecekan spesimen: Kjellberg (84 \& 100), Rante Lemo; FIW/SMBU/3, S. Tubelo, Sultra.

Etropothecium dealbatum (Hornsch \& Reinw.) Jaeg., dalam Adumbr. 2: 528 (18771878)

Sinonim: Hypnum dealbatum Hornsch. \& Reinw., dalam Nov. Act. Acad. Caes. Leop.
Coral 14 Suppl. 2:729 (1828); Ecrtropothecium assimile Broth., dalam Philip. J. Sci. § C 5:153 (1910).

Tubuh berukuran kecil. Cabang berdaun merata. Daun lanset, bergerigi ke arah ujung. Sel-selnya berbanding 12:1 atau 16:1, bagian tepi terdeferensiasi. Seta ramping, merah, panjang0.8 mm, tutup kapsul cembung, berparuh tajam.

Ekologi dan persebaran: umumnya tumbuh di batang pohon, demikian juga di lokasi penelitian ditemukan pada substrat yang sama. Bartram (1939) melaporkan bahwa jenis ini tersebar di Sumatra, Jawa, Borneo dan Filipina. Pengecekan specimen: P. Buwalda 3711, Bantimurung; FIW 307, TN Bogani Nani Wartabone; FIW/SMBU/45, G. Wani, Sultra.

Isopterygium Mitt., dalam J. Linn. Soc. 12: 21 (1869)

Berperawakan ramping, membentuk jalinan pipih. Daun membundar telur - lanset, sering tidak simetris, rata atau bergigi kecil di bagian atas. Sel-sel linear, kadang berpapila di ujungnya. Seta halus, memanjang, kapsul kecil, merunduk, peristom rangkap dan sempurna, tutupnya mengerucut. Dua jenis ditemukan di lokasi penelitian dan dapat dibedakan dari posisi kapsulnya, pada Isopterygium bancanum posisi kapsul merunduk sedangkan Isopterygium albescens mendatar.

\section{Isopterygium bancanum (Lac.) Jaeg., dalam Adumbr. 2: 508 (1877-1878)}

Sinonim: Hypnum bancanum Lac., dalam Bryol. Jav. 2: 188 (1868).

Hiijau kekuningan. Percabangan longgar. Daun tersebar melebar, cekung, bergerigi tajam mulai pertengahan hingga ujung. Seta 10-14 mm panjangnya, ramping.

Ekologi dan persebaran: umumnya tumbuh di batang pohon atau bebatuan. Di lokasi penelitian ditemukan di batuan, tepi sungai. Bartram (1939) melaporkan bahwa jenis ini tersebar di Sumatra (Bangka), Jawa dan Filipina, namun pada pengecekan spesimen di Herbarium Bogoriense juga ditemukan di Sulawesi seperti koleksi FIW 775 \& 877, TN Bogani Nani Wartabone; FIW/SMBU/22 \& FIW/SMBU/ 28, S. Tubelo, Sultra. 
Isopterygium albescens (Schwaegr.) Jaeg., dalam Adumbr. 2: 499 (1876-1877)

Sinonim: Hypnum albescens Schwaegr., dalam Suppl. pt, 13 fasc. 2 (1828) pl. 226.

Kuning cerah atau hijau perak, lembut. Panjang batang mencapai $3 \mathrm{~cm}$, cabang ramping, daunnya jarang. Daun tersebar melebar, deretan lateral tidak simetris, membundar telur- lanset, cekung, rata atau bergigi kecil, ujung meruncing ramping, tidak berkosta. Sel-sel linear, halus. Seta seperti benang, kemerahan, 15-18 mm panjang, kapsul membulat telur.

Ekologi dan persebaran: umumnya tumbuh di batang pohon, kayu-kayu lapuk atau tercampur dengan lumut lain di pangkal pohon (So, 1995), di lokasi penelitian jenis ini (FIW/SMBU/5, S. Tubelo, Sultra) ditemukan tumbuh di bebatuan, tepi sungai. Daerah persebarannya meliputi: Himalaya, Ceylon, Sumatra, Jawa, Borneo, Sulawesi, Jepang, Pulau-pulau di Pasifik hingga Hawaii (Bartram, 1939).

\section{Meteoriaceae}

Berperawakan ramping, halus atau kekar, menggantung, membentuk masa yang berbulu. Batang menyerupai benang, menjalar, cabang memanjang, membelit, berdaun padat. Daun membundar telur-lanset, meruncing, kosta biasanya tunggal, ramping, berakhir di bawah ujung daun. Sel-sel memanjang, sering berpapila. Kapsul biasanya ramping, seta pendek, peristom rangkap, bertutup pendek, kaliptra kecil, mengangguk, sering dengan rambut-rambut panjang. Suku ini terdiri atas beberapa marga, salah satu jenis dari anggota suku ini ditemukan di lokasi penelitian yaitu Barbella pendula.

\section{Barbella pendula (Sull.) Fleisch, dalam} Laubmfl. Java 3 : 312 (1907)

Sinonim: Meteorium pendulum Sull., dalam Mosses of U.S. 81 (1856); Barbella

Kunci identifikasi marga:

1 a. Tumbuhan berperawakan kekar atau ramping,

b. Tumbuhan berperawakan kecil

2 a. Batang bercabang menyirip rangkap ....

b. Batang bercabang menyirip tunggal

3 a. Kapsul muncul pada seta yang pendek

b. Kapsul tenggelam. ... elongata Williams, dalam Bull. N.Y.Bot. Garden 8: 356 (1914).

Berperawakan sangat ramping, halus, mengkilat, hijau kekuningan, batang 50-60 cm panjangnya, bercabang menyirip tak beraturan. Daun-daun pada batang 2.5-3 mm panjangnya, membundar hingga melanset, berakhir sebagai bentuk benang, tepinya tegak, bergerigi lemah, kosta halus, berakhir di atas pertengahan daun. Sel-selnya panjang dan ramping, berpapila halus, sel-sel alar pendek mengelompok di sudut pangkal daun. Daun-daun cabang sama tetapi ukurannya lebih kecil dan sel-selnya lebih lebar. Sporofit lateral, muncul di akhir cabang; seta 2-3 mm panjangnya, kadangkadang melengkung, kapsul oblong-silindris, gigi peristom bergaris trasversal.

Ekologi dan persebaran: umumnya tumbuh di cabang atau ranting pohon, di lokasi penelitian ditemukan merambat di batang pohon. Jenis ini dilaporkan sebagai catatan baru bagi Sulawesi berdasarkan laporan dari Bartram (1939) yang menyatakan bahwa daerah persebarannya meliputi Ceylon, Sumatra, Jawa, Filipina, China, Jepang, Formosa, dan Amerika. Disamping itu hasil pengecekan spesimen herbarium juga tidak menemukan koleksi dari Sulawesi selain koleksi FIW/SMBU/ 33, S. Tubelo, Sultra.

\section{Neckeraceae}

Berperawakan kekar, mengkilat. Batang menyerupai benang, menjalar, bercabang menyirip, pipih, tegak atau menggantung. Daun biasanya bergelombang transversal, ujung pendek. Kosta tunggal, jarang rangkap dan pendek. Sel-sel halus, persegi enam membundar ke arah ujung, linear ke arah pangkal. Sporofit lateral, kapsul tenggelam atau muncul ke permukaan, peristom rangkap. Sebanyak 4 marga ditemukan di lokasi penelitian. 


\section{Himantocladium Fleisch., dalam Hedwigia 45: 72 (1906)}

Batang dengan percabangan jarang atau memadat, ujung percabangan seperti kipas. Daun tersusun dalam 8 deret, berligula, ujung membundar, kosta tunggal, berakhir melembut di bawah ujung daun. Sel-selnya romboid tidak beraturan, halus. Kapsul tegak, gigi peristom berpapila, kaliptra kecil, kadang berbulu. Tiga jenis ditemukan di lokasi penelitian.

Kunci identifikasi jenis:

1 a. Tumbuhan mengkilat 2

b. Tumbuhan tidak mengkilat........................................................... H. plumula

2 a. Percabangan kurang pipih, berakhir sebagai bentuk flagella............................ H. cyclophyllum b. Percabangan sangat pipih, jarang

H. Loriforme

Himantocladium cyclophyllum (C. Mull) Fleisch., dalam Laubmfl. Java 3: 887 (1907)

Sinonim: Neckera cyclophyla C.Mull., dalam Syn. 2: 664 (1851); Neckera warburgii Broth., dalam Monsunia 1: 49 (1900).

Hijau kekuningan. Batang mencapai 10 $\mathrm{cm}$ panjangnya, bercabang menyirip tidak beraturan, tegak. Daun pipih, dibedakan antara daun dorsal dan ventral, bergelombang transversal, berligula ramping di pangkal yang membundar telur, tepi bagian bawah bergigi sedang bagian atas bergerigi tidak teratur, kosta kaku, ujung membundar. Sel-sel memendek ke arah ujung dan memanjang ke arah pangkal. Seta $1.5-2 \mathrm{~mm}$ panjangnya, kapsul tegak, silindris, gigi peristom ramping.

Ekologi dan persebaran: umumnya tumbuh di batuan pada ketinggian mencapai $300 \mathrm{~m}$ atau lebih di atas permukaan laut ( So, 1995). Sedangkan d lokasi penelitian jenis ini (FIW/SMBU/ 8, S. Tubelo, Sultra) ditemukan di kayu-kayu lapuk, tepi sungai. Daerah persebarannya meliputi: Jawa, Sulawesi, Nugini, Filipina, dan Tahiti (Bartram, 1939).

Himantocladium loriforme (Lac.) Fleisch., dalam Laubmfl. Java 3 : 884 (1907)

Sinonim: Neckera loriforme Lac., dalam Bryol. Jav. 2 : 63 (1863).

Jenis ini mirip dengan $H$. cyclophyllum tetapi mempunyai percabangan lebih jarang dan tampak lebih mengkilat. Percabangannya sangat pipih, semua daun tersebar lateral dan tidak dibedakan antara sisi dorsal dan ventral.

Ekologi dan persebaran: jenis ini di lokasi penelitian ditemukan di kayu-kayu lapuk tepi sungai pada ketinggian lebih dari $300 \mathrm{~m}$ di atas permukaan laut. Persebarannya meliputi Jawa, Sulawesi, Borneo, Nugini, Filipina, Fiji, dan Samoa (Bartram, 1939). Pengecekan spesimen: FIW 874,853 \& 779, TN Bogani Nani Wartabone; FIW/SMBU/15, FIW/SMBU/ 17b, FIW/SMBU/ 18b, S. Tubelo, Sultra.

Himantocladium plumula (Nees) Fleisch, dalam Laubmfl. Java 3: 889 (1907)

Sinonim: Pilotrichum plumula Nees, dalam Brid. Bryol. Univ. 2: 759 (1827).

Sinoikus (anteridia dan akegonia berada dalam satu klaster), hijau kekuningan. Percabangan tegak, 4-6 cm panjangnya, memadat di bagian atas menyerupai kipas. Daun berdesakan, kadang memipih, kasar, berligula, ujung membundar dengan bagian tengah runcing, bergerigi kecil ke arah ujung; kosta kaku, berakhir halus di bawah ujung daun, sering menggarpu di ujungnya. Sel-sel persegi enam tidak beraturan, berdinding jernih, perlahan-lahan menjadi persegi ramping ke arah pangkal. Seta $1.5 \mathrm{~mm}$ panjangnya, kadang-kadang melengkung, kapsul tegak, membulat-silindris, gigi peristom berpapila.

Ekologi dan persebaran: biasanya tumbuh di batang pohon sedangkan di lokasi penelitian ditemukan di kayu lapuk. Jenis ini merupakan catatan baru bagi Sulawesi yang didasarkan pada laporan Bartram (1939) bahwa daerah persebarannya meliputi: Sumatra, Jawa, Borneo, Filipina dan New Caledonia dan hasil pengecekan spesimen di Herbarium Bogoriense yang tidak menemukan jenis ini dikoleksi dari Sulawesi, kecuali koleksi FIW/SMBU/ 17a \& FIW/ SMBU 18a, S. Tubelo, Sultra.

\section{Neckeropsis Reichd't., dalam Novara Exped.} Bot. 1 : 181 (1870)

Berperawakan ramping atau kekar, mengkilat, bercabang menyebar, sangat pipih. 
Daun tersusun 4 deret, tersebar mendatar, bergelombang, ujung membulat lebar, kosta tunggal berakhir di pertengahan daun atau rangkap dan pendek. Sel-sel halus, romboid pendek di bagian ujung, memanjang di bagian pangkal. Kapsul tenggelam dalam daun-daun pelindung yang besar, peristom rangkap, kaliptra kecil, berambut. Satu jenis dari marga ini ditemukan di lokasi penelitian dan tumbuh pada ranting-ranting pohon tepi sungai yaitu Neckeropsis lepineana.

Neckeropsis lepineana (Mont.) Fleisch., dalam Laubmfl. Java 3: 879 (1907)

Sinonim: Neckera lepineana Mont., dalam Ann. Sci. Nat. 107; Syll. 23 (1848).

Berperawakan kekar, hijau kekuningan, menggantung. Cabang tidak beraturan, mencapai $30 \mathrm{~cm}$ panjangnya. Daun sangat bergelombang, berligula melebar dari pangkal daun yang menjepit, bagian atas bergerigi kecil, kosta sangat pendek dan halus, menggarpu tidak sama panjang. Sel-sel dengan ketebalan dinding tidak sama. Sporofit pendek, tumbuh pada cabang lateral, kapsul muncul di atas seta yang sangat pendek, gigi peristom berpapila.

Ekologi dan persebaran: jenis ini ditemukan di ranting pohon dan tersebar di Afrika Timur, Malesia, Pulau-pulau di Pasifik hingga Hawaii (Bartram, 1939). Pengecekan spesimen: FIW (837,875,807,781, 817 \& 870), ITN Bogani Nani Wartabone; Wuljarni (154), Lemo, Tana Toraja; P. Buwalda (3707), Bantimoeroeng; Dewi (sn), Desa Sedoa, Sulawesi Tengah; FIW/SMBU/25 \& FIW/ SMBU/34, S. Tubelo, Sultra.

\section{Pinnatella (C.Mull.) Fleisch., dalam Hedwigia 45: 79 (1906)}

Berperawakan kecil, memberkas, hijau kekuningan. Batang menjalar, percabangan menyebar, tegak, menyirip rangkap, pangkal cabang berkayu atau kadang-kadang memipih. Daun membundar telur, cekung, halus, jarang bergelombang, beralur memanjang di sisi kosta, bagian atas bergigi kecil, ujung pendek, kosta kuat, berakhir mendekati ujung daun. Selsel membundar-persegi enam, sering berpapila kecil, bagian pangkal linear. Seta pendek, berpapila, kapsul tegak, membulat telur, peristom rangkap. Satu jenis dari marga ini ditemukan di lokasi penelitian yaitu Pinatella ambigua.

\section{Pinatella ambigua (Lac.) Fleisch., dalam Hedwigia 45 :81 (1906)}

Sinonim: Thamnium ambiguum Lac., dalam Bryol. Jav. 2: 72 (1863).

Hijau tua kekuningan, ramping. Panjang batang mencapai $4 \mathrm{~cm}$, daun berdesakan di atas. Daun-daun cabang kecil, lemah, cekung, oblong-membundar telur, runcing, bergigi kecil dan lemah ke arah ujung, melipat jika kering. Daun batang berukuran lebih besar. Sel-selnya berdinding tipis, halus, lebih kecil di bagian tepi, perlahan lahan menjadi rectangular ke arah pangkal. Seta $3 \mathrm{~mm}$ panjangnya, kadangkadang melengkung, kuning.

Ekologi dan persebaran: umumnya ditemukan tumbuh di ranting pohon, sedang di lokasi penelitian ditemukan di perakaran yang muncul di atas tanah di lereng gunung. Jenis ini (FIW/SMBU/ 26, Gn. Wani, Sultra) merupakan catatan baru bagi Sulawesi, didasarkan pada laporan Bartram (1939) bahwa daerah persebarannya meliputi Bhotan, Burma, Sumatra, Jawa dan Filipina serta hasil pengecekan spesimen di Herbarium Bogoriense yang tidak pernah menemukan koleksi dari Sulawesi. Spesimen yang ada berasal dari Kalimantan Timur dikoleksi oleh H. udjatmiko (028).

Calyptothecium Mitt., dalam J. Linn. Soc. Bot. 10: 190 (1868)

Berperawakan kekar, mengkilat. Percabangan tumbuh tegak atau menggantung, menyirip halus atau rapat, cabang memipih, membundar di ujung. Daun berdesakan, tersusun dalam 8 deret, oblong - lanset atau berligula, bergelombang transversal, pangkal bercuping, ujung meruncing pendek, bergerigi; kosta ramping, berakhir di atas pertengahan daun. Sel-sel linear halus, jarang. Kapsul tenggelam, gigi peristom halus. Satu jenis dari marga ini ditemukan di lokasi penelitian yaitu Calyptothecium caudatum.

Calyptothecium caudatum Bartram, dalam Philip. J. Sci. 68: 237 (1939)

Cabang sangat pipih, berakar, mencapai $8 \mathrm{~cm}$ panjangnya, ujungnya berdaun kecil dan membulat. Daun sangat pipih, tersebar melebar, 
menjantung, cekung, meruncing pendek, tepi tegak, bergigi kecil dekat ujung, kosta ramping berakhir 2/3 dari panjang daun.

Ekologi dan Persebaran: jenis ini dilaporkan Bartram (1939) sebagai jenis baru dan endemik di Filipina yang tumbuh di ranting pohon, di lokasi penelitian jenis ini (FIW/SMBU/16, S. Tubelo, Sultra) juga ditemukan di kayu mati pinggir sungai. Dengan demikian status endemik dari jenis ini dapat di rubah, dan jenis ini merupakan catatan baru bagi Sulawesi.

\section{Pottiaceae}

Batang tegak, kecil hingga medium. Daun lanset, berspatula atau berligula, tepi rata, beberapa jenis ada yang menggulung ke dalam atau menggulung ke luar. Kosta menonjol, berakhir di luar ujung daun. Sel-sel lamina persegi, kadang-kadang halus tetapi umumnya berpapila, sel-sel bagian pangkal halus, memanjang dan jernih. Sporofit tegak, peristom pendek atau memanjang. Satu jenis dari suku ini ditemukan tumbuh di batuan tepi sungai.

\section{Barbula arcuata Griff., dalam Calcuta J.Nat.Hist. 2: 491 (1842)}

Sinonim: B. comosa Dozy \& Molk, dalam Annls Sci.nat.Bot., ser.3(2) : 299 (1844); B. sobolifera Fleisch., dalam Musci Fl. Buitenzorg 1: 351(1904); B. subulata Broth., dalam Philipp. J. Sci. 31: 282 (1926); B. steerei Bartr., dalam Philipp. J. Sci. 71: 421 (1940).

Tumbuhan memberkas, hijau-kuning hingga coklat tua, batang mencapai $2.5 \mathrm{~cm}$ tingginya. Daun tersebar tegak jika basah, terpuntir jika kering, melengkung, pangkal melebar, kemudian tiba-tiba meruncing dan membentuk subula di ujungnya, tepinya menggulung. Kosta berakhir di ujung daun atau kadang-kadang di bawah ujung daun. Sel-sel lamina pendek persegi panjang, kadang-kadang persegi, berdinding tipis. Seta kemerahan, 10$14 \mathrm{~mm}$ panjangnya, kapsul silindris, peristom tidak mudah runtuh, seperti rambut, sama panjang, terjalin membentuk spiral.

Ekologi dan persebaran: umumnya tumbuh di batu atau tanah basah tepi sungai, pada ketinggian kurang dari $1500 \mathrm{~m}$ di atas permukaan laut. Daerah persebarannya di Asia tropis dan subtropis dari India dan Sri Lanka hingga Jepang, di kawasan Malesia ditemukan dari Filipina hingga Jawa dan Sumatra, ke arah timur jarang ditemukan (Eddy, 1990). Di lokasi penelitian jenis ini (FIW/SMBU/31, S. Tubelo, Sultra) ditemukan tumbuh pada batuan di tepi sungai.

\section{Sematophyllaceae}

Tumbuhan berperawakan ramping atau kekar, memberkas padat atau membentuk bantalan. Sering mengkilat. Batang menjalar atau tegak, bercabang menyirip. Daun membundar telur, meruncing, kosta pendek dan rangkap atau tidak ada. Sel-sel lamina memanjang, halus atau berpapila, sel-sel alar berwarna, mengelompok di sudut basal daun, pipih. Seta memanjang, halus atau berpapila , kapsul kecil, merunduk atau mendatar, peristom berkembang sempurna, tutup kapsul berparuh, kadang-kadang mengerucut, kaliptra mengangguk. Satu jenis dari suku ini ditemukan di lokasi penelitian, tumbuh di batang pohon.

\section{Taxithelium alare Broth., dalam Philip. J.} Sci. C3 : 28 (1908)

Berperawakan ramping, hijau kekuningan, mengkilat, membentuk bantalan pipih. Batang menjalar, bercabang menyirip, panjang cabang $1 \mathrm{~cm}$. Daun berdesakan, tersebar tegak, membundar telur lanset, cekung, bagian tepi tegak, ujung perlahan-lahan mengecil membentuk bulu / rambut, kosta tidak ada. Sel-sel linear, ramping, berpapila kecil, sel alar 3-4, membundar telur, pipih, kekuningan, sangat berbeda dengan sel-sel lain di atasnya. Seta ramping, kemerahan, halus, 2-3 cm panjangnya; kapsul kecil, merunduk, tutup mengerucut.

Ekologi dan persebaran: umumnya tumbuh di ranting pohon dan dilaporkan sebagai jenis endemik di Filipina (Bartram, 1939). Hasil pengecekan spesimen di Herbarium Bogoriense telah menemukan jenis ini pernah dikoleksi di Indonesia (Clemens (40047 \& 34096), FIW dan Y. Yamaguchi (21825) dari Kalimantan). Dengan ditemukannnya jenis ini (FIW/SMBU/49, G.Wani, Sultra) di lokasi penelitian serta didasarkan hasil pengecekan spesimen koleksi di Herbarium Bogoriense maka status 
endemiknya dapat berubah dan merupakan catatan baru bagi Sulawesi.

\section{Thuidiaceae}

Tumbuhan berperawakan ramping atau kekar. Batang merayap, bercabang menyirip teratur 2 atau 3 kali, biasanya dengan parafilia. Daun dibedakan menjdi dua macam yaitu daun batang dan daun cabang, berkosta tunggal, kaku. Seta memanjang, halus, kapsul mendatar, peristom rangkap, tutup kapsul berparuh atau mengerucut. Salah satu marga dari suku ini ditemukan di lokasi penelitian.

Thuidium Br. \& Schimp., dalam Bry. Eur. Fasc. 49 to 51 (1852)

Batang dengan percabangan membentuk jalinan seperti bulu, berparafilia melimpah. Daun batang besar, melebar, pangkal menjantung, ujung meruncing; daun cabang kecil, membundar, cekung, berujung pendek. Sel-selnya membundar, berpapila. Kapsul biasanya merunduk atau mendatar; tutup kapsul berparuh. Dua jenis dari marga ini ditemukan di lokasi penelitian dan dapat dibedakan dari perawakannya, pada Thuidium investe berperawakan kecil dan lembut sedangkan Thuidium plumulosum berperawakan besar dan percabangannya membentuk jaringan berbelitbelit.

\section{Thuidium investe (Mitt.) Jaeg., dalam Adumbr. 2: 318 (1876-1877)}

Sinonim: Hypnum investe Mitt., dalam Hook. J. Bot. (1856):355; Leskea investe Mitt., dalam J. Linn. Soc. Suppl. 1 (Musc.Ind.Or.) (1859): 135.

Hijau kecoklatan. Batang bercabang menyirip ganda, parafilia kecil, cabang seperti kapiler. Daun batang halus, membundar telur, meruncing pendek, daun cabang lebih kecil, melengkung jika kering, kosta berakhir sebelum ujung daun. Seta $1 \mathrm{~cm}$ panjangnya, halus di bagian bawah, kasar di atas, kapsul relatif besar, tutup kapsul panjang dan berparuh ramping.

Ekologi dan persebaran: umumnya tumbuh di batuan dan tersebar di Burma dan Filipina (Bartram, 1939). Jenis ini (FIW/SMBU/1, S. Tubelo, Sultra) merupakan catatan baru bagi Sulawesi didasarkan pada laporan Bartram (1939) dan hasil pengecekan koleksi di Herbarium Bogoriense yang tidak pernah menemukan koleksi jenis ini berasal dari Sulawesi. Koleksi yang ada berasal dari Kalimantan Timur oleh Heri Sudjatmiko 067.

Thuidium Plumulosum (Doz.\& Molk.) Doz. \& Molk., dalam Bryol. Jav. 2 (1865) : 118

Sinonim: Thuidium meyenianum (Hampe) Doz. \& Molk., dalam Bryol. Jav. 2 (1865):121; Hypnum plumulosum Doz.\& Molk., dalam Ann. Sci. Nat. (1844): 308; Hypnum meyenianum Hampe, dalam Ic. Musc. (1844) pl. 8.

Hijau tua, batang memanjang, keras dan liat, tegak atau melengkung, bercabang menyirip ganda sangat teratur dan rapi, parafilia padat. Daun batang segitigamembundar telur pangkalnya, terlipat halus, tiba-tiba meruncing di bagian yang lebar, tepi melengkung, kosta berakhir sebagai ujung yang ramping. Daun cabang lebih kecil, membundar telur, berujung pendek. Sel-sel persegi enam tak beraturan, berpapilla tunggal, sedang sel-sel apikal dengan 2-3 papila. Seta kaku, berpapila, 2.5-3 mm panjangnya, kapsul merunduk, melengkung, oblong-silindris, peristom besar, kemerahan, tutup kapsul mengerucut.

Ekologi dan persebaran: Touw dan Haak (1989) melaporkan bahwa jenis ini pernah ditemukan di pangkal batang pohon, kayu mati dan batuan kapur, pada ketinggian kurang dari $500 \mathrm{~m}$ di atas permukaan laut. Di lokasi penelitian ditemukan di akar pohon dan batuan di tempat yang terbuka. Daerah persebarannya meliputi: Himalaya, Ceylon, India Timur, Annam, Sumatra, Jawa, Maluku, Nugini, Fiji dan Pulau Solomom (Bartram, 1939); Marianas, Caroline, Vanuatu, New Caledonia dan Samoa (Touw dan Haak, 1989). Pengecekan spesimen: FIW 809, TN Bogani Nani Wartabone; FIW/SMBU/37, S. Tubelo, Sultra.

\section{Kesimpulan}

Keanekaragaman lumut (Musci) yang ditemukan di lokasi penelitian relatif sangat rendah, disebabkan oleh curamnya medan dan curah hujan yang cukup tinggi. Lumut 
ditemukan melimpah di sepanjang tepi sungai sedang di lereng gunung jarang ditemukan. Dari 26 jenis lumut yang ditemukan di lokasi penelitian tercatat sebanyak 6 jenis merupakan rekaman baru bagi Sulawesi.

\section{Ucapan Terima Kasih}

Penelitian ini terlaksana atas dana dari proyek Inventarisasi dan Karakterisasi Sumber Daya Hayati, Pusat Penelitian Biologi LIPI dan perijinan dari BKSDA Sulawesi Tenggara. Untuk itu penulis mengucapkan terimakasih atas kerjasamanya kepada Kepala Puslit Biologi, Kepala Bidang Botani, Pimpinan proyek, dan Kepala BKSDA Sulawesi Tenggara serta semua pihak yang terkait dengan kegiatan penelitian ini.

\section{Daftar Pustaka}

Anonim. 1999. Informasi kawasan Konservasi Propinsi Sulawesi Tenggara. Departemen Kehutanan Kantor Wilayah Sulawesi Tenggara, Sub Balai Konservasi Sumber Daya Alam Sulawesi Tenggara. 24-25.

Bartram, E.B. 1939. Mosses of Philippine. Dalam The Philippine J. of Sciencen 68: 1-435.

Dixon, N.H. 1939. Moss of Celebes. Annales Bryologici V (7): 19-36.

Eddy, A. 1988. A. Handbook of Malesian Mosses Volume 1. Natural History Museum Publications, London. 204 halaman.

Eddy, A. 1990. A. Handbook of Malesian Mosses Volume 2. Natural History Museum Publications, London. 256 halaman.

Ellis, L.T. and Tan, B.C. 1999. The Moss family Calymperaceae (Musci) in the Philippines. Bull. nat. Hist. Mus. Lond. (Bot.) 29 (1): 1-46.

Richard, R.W. 1984. Ecology of Tropical Forest Bryophyte. In: Schuster, R.M. (Eds.). New Manual of Bryology Voleme 2, The Hattori Botanical Laboratory, Nichinan, Miyazaki, Japan. 1295 halaman.
Richardson, D.H.S. 1981. The Biology of Mosses. Blackwell Scientific Publications, Oxford London Edinburgh Boston Melbourne. 220 halaman.

Rugayah, Retnowati, A., Windadri, F.I. dan Hidayat, A. 2004. Pengumpulan data taksonomi. Pedoman pengumpulan data keanekaragaman flora. Pusat Penelitian Biologi, Bogor - Indonesia.

So., M.L. 1995. Mosses and Liverworts of Hongkong Volume 1. Heavenly People Depot. Hongkong. 162 halaman.

Touw, A. and van den Haak, L.F. 1989. A Revision of The Australasian Thuidiaceae (Musci), with Notes on Species from Adjacent Regions. $J$ Hattori Botanical Laboratory 67: 1-57.

Uji, T., Mansyur, M., Windadri, F.I., Sujadi, A. dan Dirman. 2003. Laporan perjalanan: Keanekaragaman dan Potensi Flora di Suaka Margasatwa Buton Utara dan sekitarnya Sulawesi Tenggara. Bidang Botani Pusat Penelitian Biologi-LIPI, Bogor. 26 halaman.

Uji, T., Rustiami, H., Windadri, F.I., Mansyur, M., Purwaningsih, S., Mulyadi, Sujadi, A. dan Wardi. 2004. Laporan perjalanan: Keanekaragaman dan Potensi Flora dan di Suaka Margasatwa Buton Utara dan sekitarnya Sulawesi Tenggara. Bidang Botani Pusat Penelitian Biologi-LIPI, Bogor. 26 halaman.

Van Steenis, C.G.G.J. 1950. Flora Malesiana 1. Noordhoff-Kolff N.V. Djakarta.

Windadri, F.I. 1996. Flora lumut di Gugusan Bukit Gunung Kabila, Taman Nasional Bogani Nani Wartabone, Sulawesi Utara. In: Arief, A.J., Said, D.S., Jamal, Y., Paryanti, S., Sulistiono, H., Rochadi, Harsono, E. Laporan Teknik Proyek Penelitian, Pengembang dan pendayagunaan Biota Darat Tahun 1995/1996. Pusat Penelitian dan Pengembangan Biologi LIPI, Bogor. 447-453. 